\title{
タイ人はラフカディオ・ハーンの「日本人の微笑」をどう解釈するか。
}

\section{OPOTHISITTHIPORN TIPPAYARAT ${ }^{1}$ 米谷淳 ${ }^{2}$ 林萍萍 ${ }^{1}$}

(神戸大学大学院国際文化学研究科 神戸大学大学教育推進機構)

Key words: comparison between Japanese and Thai, “Japanese Smile" , reading comprehension

\section{目 的}

“Japanese Smi le” (Hearn, 1895) の発表以降、日本人が人 前で「西洋人の謎」である微笑みをよくすることが世界的に よく知られるようになった。タイ国は Land of Smile と呼ば れるように、タイ人の微笑みも世界中に知られている(例えば、 松下, 1995）。日本人とタイ人は、ハーンの『日本人の微笑』 に描かれた微笑みをどのように解釈するだろうか。これを検 討する手始めに、日タイの大学生に文章を読ませ、読み取り 方を調べてみたので、ここに報告する。

\section{方 法}

回答者 日本人大学生 38 名 (男性 21 名, 女性 13 名, 不明 3 名, 平均年齢 19.5 歳・S D 1.28)。タイ人大学生 65 名 (男 性 16 名, 女性 49 名, 平均年齢 20.8 歳 - S D 0.58)。

手続き『日本人の微笑』(小泉, 1975)において微笑みが 描写されている以下の 3 場面を読ませ、微笑についてどう理 解するか」、「日常生活の中で同じような体験をしたことがあ るか」質問した。タイ人には、研究者が訳したタイ語の質問 紙を使用した。教室で授業中に学生に質問紙を配布し、回答 してもらい回収した。調査は匿名で実施した。

場面1イギリス人紳士が日本人を責めたところ、日本人が微笑みを浮が゙た。(p247-248) 場面 2 家政婦が、夫の骨が入った壸を雇い主の婦人に見せながら笑っていた。(p249-250) 場面 3 雇い主が元侍の雇われ人を殴ったが、元侍はずっと微笑んでいた。(p250-252)

分析方法 KJ 法を用いて回答をグループ化した。タイ人の 回答は、2 人のタイ人、日本人の回答は、1 人の日本人と日本 語ができる 1 人のタイ人評定者が話し合いながらグループ化 した。その後、タイ人と日本人の回答を意味的に分析し、類 似な内容を同じグループにした。

\section{結 果}

場面 1 において、タイ人大学生の述べ回答 74units の内、 謝罪 (35units, 53. 8\%) が最も多く、次に、容認 (11units, 16. $9 \%$ )、軽荗 (7units, 10.8\%)、場をやり過ごす (5units, 7. 69\%) 、感情抑制 (4units, 6.15\%)の順であった。一方、日 本人大学生の述べ回答 38units の内、場をやり過ごす (12units, 31. 6\%) が最も多く、次に、理解不能 (6units, 15. 8\%) 、謝罪 (5units, 13. 2\%) 、軽䘷 (5units, 13. 2\%) 、自 己アピール(5units, 13.2\%)の順であった。 $\chi^{2}$ 検定の結果、 謝罪、容認は、タイ人が日本人より回答率が有意に高く $(p<.05)$ 、理解不能、場をやり過ごす、自己アピールは、日 本人がタイ人より回答率が有意に高い $(p<.05)$ こが確かめ られた。

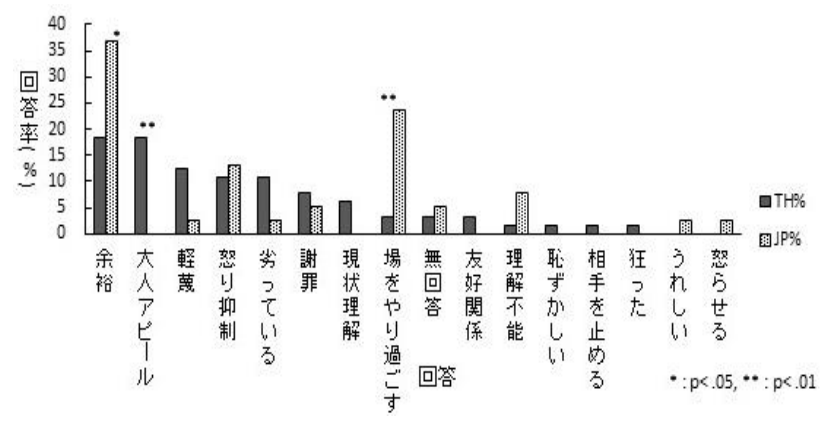

図 1 場面 1 の回答率の比較
場面 2 において、タイ人大学生の述べ回答 75units の内、 悲しみの隠ぺい (28units, 43.1\%) が最も多く、次に、喜び (15units, 23.1\%) 、現状理解 (8units, 12.3\%) 、上司に対す るマナー(6units, 9.23\%) 、自分への励まし(6units, 9. 23\%) の順であった。一方、日本人大学生の述べ回答 39units の内、 悲しみの隠ペい(13units, 34. 2\%) が最も多く、次に、喜び (10units, 26.3\%) 、上司に対するマナー(6units, 15.8\%)、 理解不能 (5units, 13.2\%) の順であった。 $\chi^{2}$ 検定の結果、現 状理解は、タイ人が日本人より回答率が有意に高い $(p<.05)$ ことが確かめられた。

場面 3 において、タイ人大学生の述べ回答 65units の内、 余裕 (12units, $18.5 \%$ ) と大としての自己アピール (12units, 18.5\%) が最も多く、次に、軽荗 (8units, 12.3\%)、 怒りの抑制 (7units, 10.8\%) 、劣っていることを認める (7units, 10.8\%)の順であった。一方、日本人大学生の述べ回 答 39units の内、余裕 (14units, 36.8\%) が最も多く、次に、 場をやり過ごす (9units, 23.7\%) 、怒りの抑制 (5units, 13. $2 \%)$ の順であった。 $\chi^{2}$ 検定の結果、大人としての自己アピ 一ルは、タイ人が日本人より回答率が有意に高く $(p<.05)$ 、 余裕、場をやり過ごすは、日本人がタイ人より回答率が有意 に高い $(p<.05) こ と か ゙$ 確かめられた。

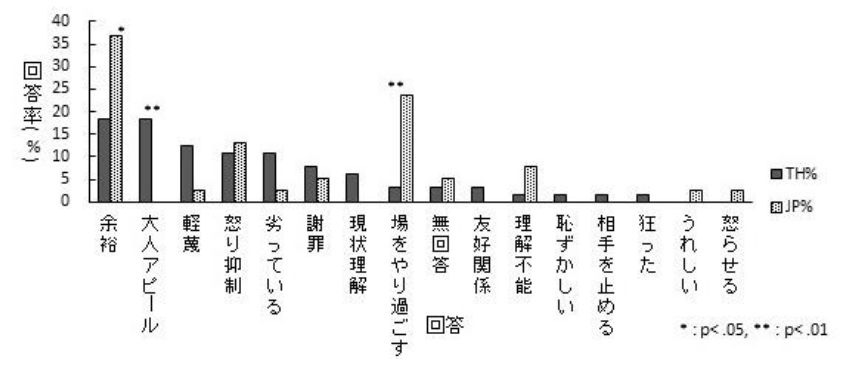

図 2 場面 3 の回答率の比較

\section{考 察}

場面 1 の微笑みは、タイ人には謝罪と解釈される傾向があ る一方、日本人には場をやり過ごすための対処と解釈される 傾向がある。場面 2 の微笑みは、タイ人にも日本人にも、悲 しみの隠ぺいと解釈される傾向があるが、その傾向は、タイ 人が日本人より強い。場面 3 の微笑みは、タイ人にも日本に 人も、余裕と解釈される傾向があるが、タイ人には、大人と しての自己アピールとも解釈される傾向があるのに対し、日 本人には場をやり過ごすための対処としても解釈される傾向 がある。

\section{引用文献}

Hearn, L. (1895). Gl impses of Unfami I iar Japan. Houghton, Mifflin.

小泉八雲 (1975). 日本人の微笑 小泉八雲著 上田和夫 訳 小泉八雲集 新潮社, 245-273.

松下 正弘(編) （1995). タイ文化ハンドブック一道標微笑 の国人一 勁草書房, 3-5.

(Tippayarat POTHISITTHIPORN, Kiyoshi MAIYA, Ping Ping LIN) 